DOI 10.15826/Lurian.2020.1.1.1

УДК 616.8(051.2)

\title{
Greetings From the Ural Federal University
}

\author{
Viktor A. Koksharov \\ Rector, \\ Ural Federal University named after the first President of Russia B. N. Yeltsin, \\ Russia, Yekaterinburg
}

\section{Приветствие от Уральского федерального университета}

\author{
Виктор А. Кокшаров \\ Ректор, \\ Уральский федеральный университет имени первого Президента России Б. Н. Ельцина, \\ Россия, Екатеринбург \\ Corresponding author.E-mail:rector@urfu.ru
}

\section{Dear Colleagues, Welcome to the Lurian Journal!}

The beginning of 2020 is marked by a significant event in scientific life of Ural Federal University in the sphere of psychology. For the first time in Russian psychology a journal aimed at preserving the legacy of Alexander Luria is started.

It is no coincidence that the Lurian Journal is initiated in the Ural region, where Alexander Romanovich Luria was a head of a large neurosurgical evacuation hospital in the settlement of Kisegach, Chelyabinsk region in 1941-1944. During this period, A.R. Luria and his staff had initiated the research and rehabilitation practice for patients with head injuries. That period made a significant contribution to the development of neuropsychological science.

Today, the Journal is focused on the development of Russian and world neu-

\section{Уважаемые коллеги, приветствуем вас на страницах “Lurian Journal”!}

Начало 2020 г. ознаменовано значимым событием в научной психологической жизни Уральского федерального университета. Впервые начинает работу психологический журнал, ориентированный на сохранение наследия Александра Романовича Лурия.

Неслучайным является открытие "Lurian Journal" именно на Урале, где с 1941 по 1944 г. Александр Романович руководил крупным нейрохирургическим эвакогоспиталем в поселке Кисегач Челябинской области. В эти годы А. Р. Лурия и его сотрудниками был проведен ряд исследований по проблемам реабилитации раненых с травмами головы. Именно данный период внес весомый вклад в развитие, прежде всего, нейропсихологической науки.

(c) Koksharov V. A., 2020 
ropsychological science by consolidating the results of the latest achievements in theoretical, experimental and applied neuropsychology. It also aims at scientific popularization of research into individual differences of people in the process of their mental, personal and professional development, their self-actualization in response to digitalization.

Joint work with outstanding scientists and experts will undoubtedly contribute to a high quality of published papers. The Journal partners include the psychologists from the Faculty of Psychology at Lomonosov Moscow State University, the Russian Academy of Education, the Russian Psychological Society and a number of scientific and psychological world centers: the American Psychological Association, the Polish Society of Neuropsychology, the Integrative Center for Neuropsychology and Psychology (Brazil), Lev Vygotsky Institute (Portugal), etc.

Everyone who is interested in preserving the heritage of A. R. Luria and developing it in contemporary context is invited for publication. We hope that the Journal will make a significant contribution to the development of Russian and world psycho$\operatorname{logy!}$
Сегодня журнал ориентирован на взаимодействие российской и мировой нейропсихологической науки путем консолидации результатов актуальных теоретических, экспериментальных и прикладных нейропсихологических исследований, в сферу его интересов также входит научная популяризация исследований индивидуальных различий субъектов в процессе психического и личностного развития, профессионального становления, самореализации в условиях цифровизации.

Несомненно, совместная работа над журналом с преподавателями факультета психологии Московского государственного университета имени М. В. Ломоносова и поддержка Российской академии образования, Российского психологического общества и ряда научных психологических центров мира: Американской психологической ассоциации, Польского общества нейропсихологии, Центра интеграции нейропсихологии и психологии (Бразилия), Института психологии им. Л. С. Выготского (Португалия) и др., позволят поддерживать высокое качество публикуемых в журнале статей.

Приглашаем к публикации всех, кто заинтересован в сохранении наследия А.Р. Лурия и его развитии в современных условиях. Надеемся, что данный журнал внесет весомый вклад в российскую и мировую психологию!

Original manuscript received April 13, 2020 Revised manuscript accepted June 13, 2020

To cite this article: Koksharov, V.A. (2020). Greetings from the Ural Federal University. Lurian Journal, 1 (1), 11-12. DOI: 10.15826/Lurian.2020.1.1.1 